\title{
ANALYSIS OF INFLUENCING FACTORS OF USE OF AGRICULTURAL LAND
}

\author{
Vita Cintina, Vivita Pukite \\ Latvia University of Life Sciences and Technologies, Latvia \\ vita.cintina@llu.lv; vivita.pukite@llu.lv
}

\begin{abstract}
Land use efficiency is based on agricultural production. Correct and effective land use could solve several problems - food production, improving the welfare and provision of social stability. The use of land and natural resources is an important issue in the development of the country; therefore, many researchers and scientists have analyzed and studied the use of agricultural land and land use efficiency. Efficient land use has an impact on different types of factors, which are mutually contradictory. In the paper several authors researches are analyzed, studying influencing factors of the use of agricultural land. Influenced by several factors the main problems associated with the use of agricultural land are the increase of unused agricultural land, the continued degradation of land, but the major problem of land use is the existence of a fragmented property structure. For the efficient use of agricultural land, there are several conditions that need to be met or improved to achieve effective land use. The main conclusion is that analyzing the problems that are associated with the use of agricultural land is seen as interactive interaction, as the fragmented property structure is one of the reasons influencing the use of agricultural land, which leads to an increase in unused areas of agricultural land, while unused areas of agricultural land are often overgrown with shrubs while promoting degradation of land.
\end{abstract}

Key words: land use, factors, land use efficiency.

\section{Introduction}

The use of land and natural resources is an important issue in the development of the country; therefore, many researchers and scientists have analyzed and studied the use of agricultural land and land use efficiency. The use of agricultural land and land use efficiency have been studied by Armands Auzins in the work "Land Use Assessment and Management"; by Irina Pilvere in the project "Economically efficient, sustainable and productive land use for agricultural and forestry production", and by several authors in the study "Factors influencing the use of agricultural land in Guilan Province, Iran", and in the work "Guidelines for Land Use Planning" the use of agricultural land is also analyzed.

Sustainable land management can promote the use of agriculture land by motivating owners to manage land, develop farms and benefit from the environment without endangering it. In turn, Irina Pilvere, within the framework of the project "Economically effective, sustainable and productive use of agricultural land and forestry production", has analyzed the use of agricultural land and the factors influencing it.

Within the framework of the project, land is analyzed in four groups of purpose of real estate use: Agricultural land, Forestry land and specially protected nature territories, where economic activity is prohibited by the regulatory enactment, Land of water objects and Land of natural base and recreational significance. Analyzing the distribution of land in the groups of purpose of real estate use according to the type of land use in Latvia in the beginning of 2010 and 2013, it can be seen that in 2013 in the group Agricultural land only $60 \%$ of land is agricultural land, whereas in the group Forestry land $85 \%$ of the area is forest and 1.8\% agricultural land (Pilvere, 2014). As a result of the analysis of these data, it can be seen that the area of agricultural land, comparing 2013 with 2010, has decreased in the groups of purpose of real estate use: Agricultural land and Forestry land and specially protected nature territories where economic activity is prohibited by the regulatory enactments, but the area of forestry land has increased in all analyzed groups of purpose of real estate use.

An increase in such forest areas and a decrease in agricultural land could be caused by the fact that agricultural land is not being properly maintained and has been overgrown with shrubs that form a forest over the years.

This study examined agricultural land characteristics and size distribution in groups according to characteristics (groomed, neglected, overgrown) in Latvia in 2012. As a result, it was ascertained that in Latvia the largest agricultural land that is groomed, neglected and overgrown is with areas of 20 to 50 hectares. It was also found that the areas of unprocessed land have increased. Of course, these results cannot be considered as completely precise, since 75,000 hectares of agricultural land are not recorded in the cadastre. Comparatively large unprocessed areas of 232.2 thousand ha or $79 \%$ in 2012 are observed in groups of property from 5 ha to 100 ha (Pilvere, 2014). As the qualitative assessment of land is also important in the use of agricultural land, the study "Economically efficient, sustainable and productive land use for agricultural and forestry production" analyzed the qualitative assessment of agricultural land in different size groups in Latvia. The qualitative assessment of 364 thousand ha or $15 \%$ of the total agricultural land is below 25 points, and 606 thousand ha or $26 \%$ is from 26 to 35 points, which suggests that these areas may have limited intensive 
agricultural production. On the other hand, a very high rating (more than 55 points) has relatively small areas - only 5\% of the total agricultural land (Pilvere, 2014).

The aim of the paper is to analyze influencing factors of the use of agricultural land. To achieve the aim, the following tasks were set:

- to analyse factors that are influencing the use of agricultural land,

- to identify key factors affecting the use of agricultural land,

- to estimate conditions for effective land use.

\section{Materials and Methods}

Land plays an important role in improving the quality of life of people, in ensuring comfort and safety, so using agricultural land should consider the conservation of fauna and flora and the availability of land resources for future generations. It is clear that changes in land use can lead to serious environmental problems; therefore, in order to plan and control the use of agricultural land and its development, it is necessary to identify and assess the factors influencing it.

Armands Auzins in his work describes land use management problems and shows the ways of solving them as well as emphasizes the importance of land use efficiency in land management. The work "Land Use Assessment and Management" analyzes the theoretical aspects of land use assessment.

The author analysing the factors influencing the results of land use has developed a model that shows the factors influencing the results of land use linking it with land management levels. The factors influencing the results of land use are indicated as follows:

1. Socio-economic factor,

2. Environmental factor,

3. Institutional factor (Auzins, 2016).

These factors also have a significant impact on the use of agricultural land and its effectiveness.

The socio-economic factor is characterized by: availability and use of land resources, introduction of innovative technologies, development of economic sectors and territories, environment and infrastructure, land capacity and productivity, living environment and population, credit facilities and investments, increase of competitiveness and use of renewable energy resources (Auzins, 2016). The use of agricultural land plays a major role in credit facilities, because the successful use of credit facilities can improve farms through the introduction of innovative technologies, as this can improve land management rapidity, save time, resources and produce more productive yields.

Land capacity and productivity also play an important role in utilizing agricultural land, the more productive the land is, the more likely it is that it will be managed and yielded. Also, great importance is the territory, place where the land is located and its population or habitat area. There is a regularity between the use of land and habitat area, for example, the larger the population, the more land is used in this territory, the less populated area, the more likely it is that the agricultural land will not be fully exploited in this area. Possibility of use of land is also influenced by the environmental factor.

Environmental factors are characterized by: biodiversity (genetic diversity, diversity of species and diversity of ecosystems), ecological integrity (ecosystem structure and processes), and natural capital (Auzins, 2016) (the soil in which we grow food, raw materials for construction and clothing, water for drinking and even the air we breathe) (Daba kā kapitāls, 2015)

An important role in agricultural land use plays the environmental factor, such as plant genetic diversity, as grazing provides greater plant diversity, the greater the chance that it will give a high energy value. Equally important is the provision of a specific area with natural capital, for example, whether there is sufficient raw material for construction (farm improvement) in this area, what is the quality of the soil (affects the type of utilization of agricultural land and its productivity), and whether there is access to water or it must also be given a boost, which can increase the cost of land use.

The use of land is also influenced by an institutional factor that is characterized as the interaction of regulatory norms and organizations (Auzins, 2016). It is important to harmonize land use with statutory norms and regulations so that the way of land use does not conflict with the norms established by law. It is also important to note that in Latvia unused agricultural land is subject to an increase in the tax rate.

Armands Auzins has analyzed not only the land use, but also the land use efficiency and factors and features influencing it, as well as sustainable land management.

The use of agricultural land is important for sustainable land management, whose mission is to maintain or improve production and provision of services, protect natural resources, ensure economic viability, prevent water quality deterioration and reduce soil degradation, reduce production risks (Auzins, 2016). In order to determine the factors influencing the use of agricultural land, it is necessary to look at the factors influencing other factors as well.

The authors of the study "Effective Factors on Agricultural Land Use Change in Guilan Province, Iran" identified five factors influencing the use of agricultural land:

1. Economic factor,

2. Social factor,

3. Governance and political factor,

4. Technical and technological factor,

5. Individual factor (Allahyari et al., 2013). 


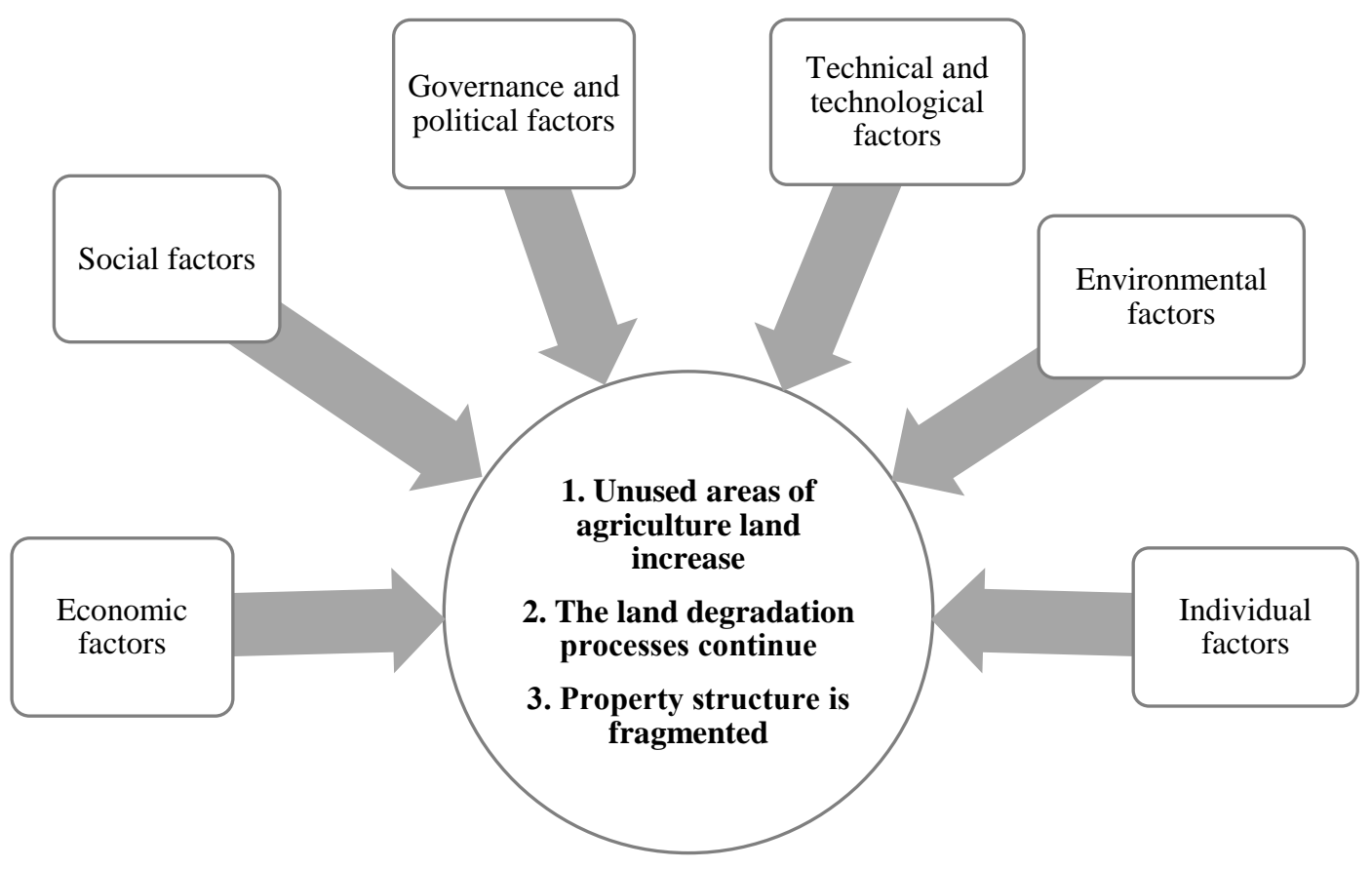

Figure 1. Factors affecting the use of agricultural land.

The economic factors are high production costs, low prices for agricultural products, resulting in a decrease in profits from the use of agricultural land. Low income creates pressure on the owners and, as a result, decreases or the owners are forced to completely abandon the management of agricultural land. Intensive use of agricultural land reduces land productivity (Allahyari et al., 2013). In order to improve the productivity of agricultural land, it is necessary to invest in, for example, land fertilization, thereby increasing the cost of utilizing agricultural land, resulting in the loss of motivation to manage this land.

Social factor is characterized by changes in the population, for example, growth in urban areas and a decrease in rural areas. An important indicator is also the level of education of the population and opportunities for attending special courses to exit from traditional agriculture (Allahyari et al., 2013). The use of agricultural land is also affected by the fact that agricultural production is largely seasonal, which has a significant impact on the number of workers.

Governance and political factors are characterized by lack of support for producers, import of products, inheritance of land, lack of support for young farmers, an increase in land rent, timely reimbursement of damages, lack of support for producers, resulting in the purchase and sale of agricultural land (Allahyari et al., 2013). Foreign imports have an impact on production, because imported products can be cheaper to purchase than local produce. The use of agricultural land is also affected by the inheritance of the land, which is related to the wishes of the new owner to sell the land, but until the documents are arranged, the land is not used. In addition, the use of agricultural land is affected by the fact that, when inheriting land, it becomes a joint property between the heirs, as a result of which this land belongs to several owners as a joint property or it is divided into real parts, which leads to fragmentation of land. Such activities may result in non-economic production.

Technical and technological factors are characterized by traditional production methods, changes in land treatment technologies, poor knowledge of the use of pesticides and chemical fertilizers, as well as inappropriate plowing system causing losses and changes in soil physical and chemical properties (Allahyari et al., 2013).

The individual factor is characterized by physically heavy work related to the use of agricultural land, as labor productivity decreases as a result of aging, which may reduce the use of agricultural land, as well as the state of health affected land use and associated changes (Allahyari et al., 2013).

In the work "Guidelines for land-use planning" problems related to the land use are listed and the land use influencing factors are defined. In this study, only three are counted as factors affecting the land use:

1. Social factor,

2. Economic factor,

3. Environmental factor (Guidelines for land ..., 1993).

Social factor indicators include the migration of people from the countryside to cities, the lack of employment opportunities in rural areas. 
Economic factor is low income and high costs of cultivating agricultural land.

Environmental factor includes inadequate water supply, excessive drought or moisture, and the spread of plant diseases.

The scheme provides a summary of the land use factors set out in works of various authors and the main problems identified in connection with the use of agricultural land (Figure 1).

As previously identified, the main problems associated with the use of agricultural land are the increase in unused agricultural land and the continued degradation of land, but the major problem of land use is the existence of a fragmented property structure. These factors are affected by the following economic, social, governance and political, technical and technological, environmental and individual factors. When problems and factors affecting the use of agricultural land are identified, it is necessary to look at the ways to ensure more efficient land use.

\section{Results and Discussion}

More efficient production processes and better environmental management systems can significantly reduce pollution and waste, and save water and other resources. Land resources have an impact on effective agricultural activity, as well as economic, social and political stability. Currently, it is not determined in Latvia how efficiently land should be used and what criteria should be taken into account in order to determine evaluation of the efficiency of land use.

Summarizing the work done by foreign authors, a theoretical model for determining the economic efficiency of land use has been obtained. The model is based on the needs and interests of the owners, as well as the interests of the state and local government. The economic efficiency of land use is characterized by the ratio between the amount of production and the cost per land unit area (Baumane et al., 2014). The efficiency of land use is reflected in materials, and labor costs can be used to determine the efficiency of production and economic land use. The efficiency of land use is influenced by the set of economic measures undertaken to improve land quality and increase productivity.

The essence of land-use efficiency is economic activity, on the one hand, and different resources, and (or) costs - on the other hand (Мишина, 2011).

Land use efficiency can be studied from different aspects:

- economic aspect-implementation of production of products, costs of production and labor,

- ecological aspect - improvement of land quality, which allows to obtain additional yield by improving economic indicators of economic activities, eliminating environmental damage,

- economically ecological aspect - the cost of complex measures aimed at improving the quality and protection of agricultural land,

- socio-economic aspect - growth indicators for assessing natural resources, preventing environmental damage,

- socio-economically ecological aspect - the transformation of solar energy at a minimal cost, the introduction of fossil fuels and the introduction of human energy with high profitability (Мишина, 2011).

Land-use efficiency differs according to land use needs, for example, whether the land is used by large agricultural enterprises: associations, cooperatives, research and education establishments or used by smaller or larger private households.

Increasing land use efficiency is a topical issue in many countries; therefore, indicators of land efficiency

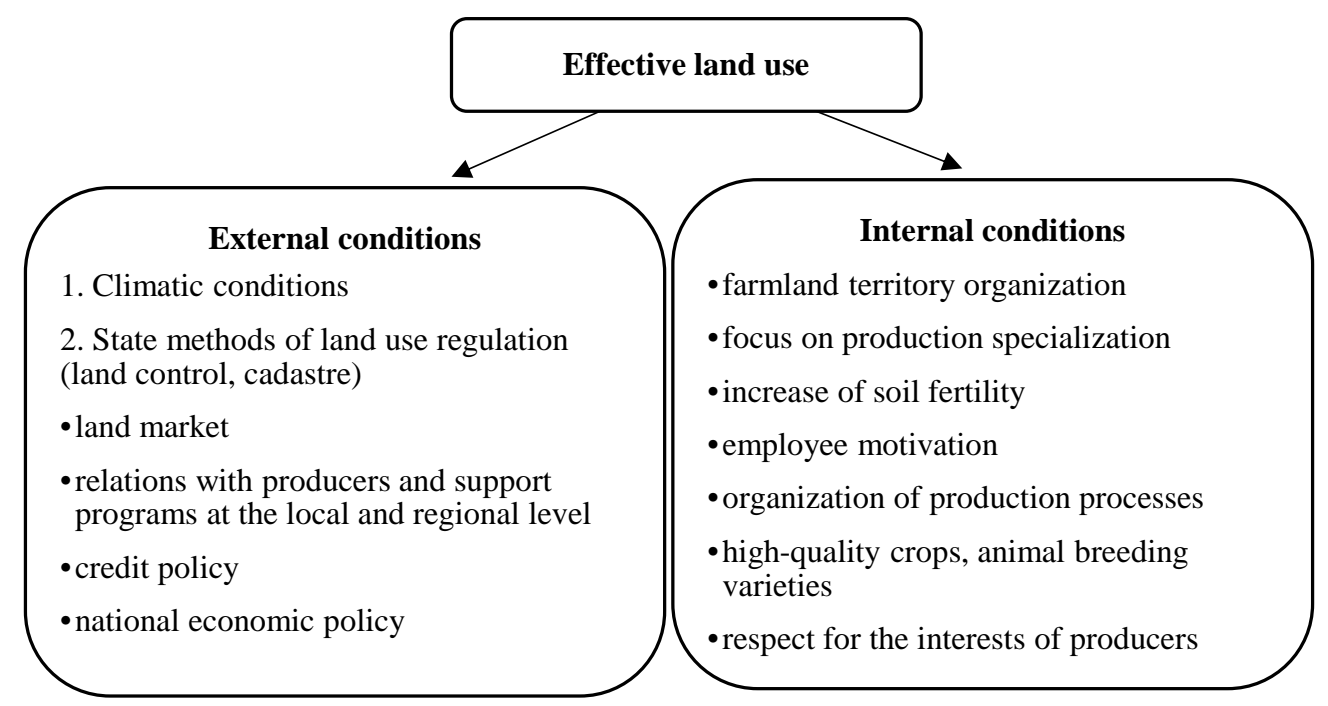

Figure 2. Conditions for effective land use. 
measurement systems and ways of calculating economic land efficiency are being developed.

The main condition for efficient use of agricultural land is the increase of soil fertility. It is based on the improvement of agricultural systems in the holdings: the organization of land areas, the planning of rotational crops, the study of the structure of the sown area, the establishment of a soil treatment system, the maintenance and installation of drainage systems, fertilizer systems, pest, disease and weed control, seed production, environmental protection measures (Колобова, 2008). The agricultural system must meet the needs of society, the ecological requirements of agriculture and crops, natural climatic conditions, the level of intensification of production, the structure of the economy, and the minimum risk of environmental pollution must be ensured. Efficient use of agricultural land (Figure 2) has both external and internal conditions that need to be met or improved to achieve effective land use.

An essential element of the effectiveness of agricultural land is the organization of land parcels, which ensures proportionality between available land and available labor, financial resources, as well as proportionality with the use of agricultural land, areas of production and specialization of agricultural holdings. Agricultural land is not used in many places because there are no balanced production factors. Due to lack of work in rural areas, people do not object to work at a lower wage, which leads to lower productivity and, in the end, to inefficient land use, as employees lack motivation to work. Land use efficiency also affects the scarcity of agricultural land, which makes it difficult to organize rotational rotation, which in time affects soil fertility.

Mechanical soil cultivation is an essential element of the effectiveness of using agricultural land as it improves soil fertility. It accounts for $30-50 \%$ of all costs in crop production. Resource-saving technology is based on cost reduction through minimal soil treatment. The use of such technologies greatly reduces the risk of soil fertility falling, as well as reduces or eliminates the effects of water and wind erosion and fuel consumption, thus increasing the total land productivity (Колобова, 2008). The use of resourcesaving technologies does not preclude the use of intensive production methods in crop production, such as the use of chemicals (herbicides and fertilization). Proper fertilization of agricultural land simultaneously improves soil fertility and increases productivity.

Seed production plays an important role in increasing the efficiency of using agricultural land (Колобова, 2008). High quality seeds with high potential yield are harvested. In the production of such seeds, timely collection and proper storage of seeds and grain selection are important.

In order to obtain high and durable results at lower costs in agricultural production, it is necessary to make all production processes in optimal time and with the optimal quality that is possible if the production process is run by highly qualified personnel with high level technologies. In turn, the use of farmed agricultural production equipment leads to a reduction in labor productivity and an increase in production costs (Колобова, 2008).

Extreme conditions affecting land use efficiency are national legislation, land policy guidelines, credit facilities, land tax rates as well as relationships with agricultural production partners at local, regional and international level.

The key role in the use of agricultural land is played by the possibilities of credit facilities and additional financial gain. State aid plays a major role in the use of agricultural land and in the production of agricultural products. As an example, the Government of the Russian Federation has developed the program "Agricultural Development" (Развитие АПК) (Колобова, 2008). State aid is provided by subsidizing interest rates on investment loans, loans are granted for the development of production on farms, leasing of equipment and breeding animals. A system of land and mortgage lending is in place, as well as access to housing necessary for young farmers and their families in rural areas.

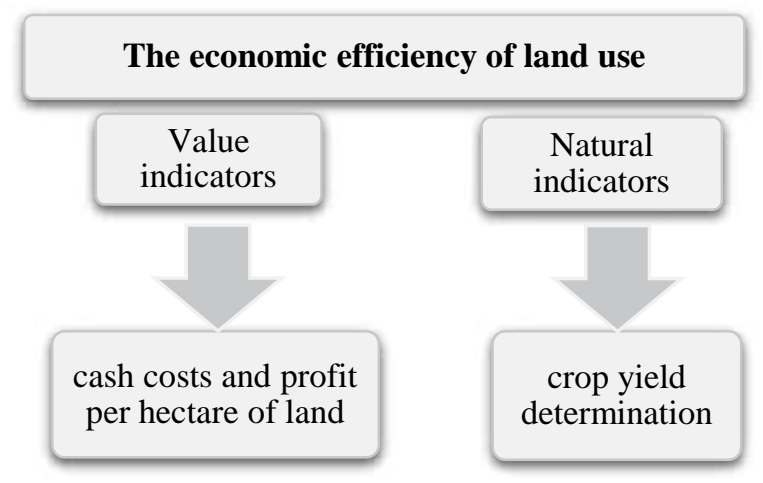

Figure 3. Indicators of economic efficiency of land use. 
In order to provide such support, it is necessary to introduce a complex set of organizational and economic measures, as well as to ensure coordinated action at all levels of state and local government. Landowners and land users are also required to provide state aid with understandable and transparent rules and regulations, as well as to create public and private sector restrictions on land use. Another important provision to increase the efficiency of the use of agricultural land is planned rational land use (Галечян, 2014). It is also necessary to ensure control and land monitoring, which is carried out in Latvia by the Rural Support Service by surveying the land and listing the total and uncultivated agricultural land. Thus, the main directions for improving and increasing the efficiency of land use are the introduction of intensive farming systems as well as clear national policies and legal regulations related to agricultural production and the use of agricultural land.

Two indicators have been developed (Figure 3), which can be used to determine the land use efficiency: the natural indicator (crop yields) and the value indicator (cash costs and profit per hectare of land).

Economical land use efficiency, which is characterized by natural and value indicators is determined most often (Изиев \& Шейхов, n.d.). The main indicators of them are the following:

- crop yields,

- income, profit per $1 \mathrm{ha}$,

- material costs, costs of land treatment,

- profitability of production, $\%$,

- the total area of land owned (ha),

- total area of treated land (ha).
Using these indicators, it is possible to determine the economic efficiency of land use, but one of the most important indicators is the determination of profitability of production, as this indicator is influenced by the location of the land and the fertility of the land.

\section{Conclusions}

1. Analyzing the problems that are associated with the use of agricultural land is seen as interactive interaction, as the fragmented property structure is one of the reasons influencing the use of agricultural land, which leads to an increase in unused areas of agricultural land, while unused areas of agricultural land is often overgrown with shrubs, thus facilitating degradation of land.

2. The use of agricultural land is influenced by economic, social, governance and political, technical and technological, environmental and individual factors, the impact of which increases or decreases the groomed land area.

3. Increasing land use efficiency is a topical issue in many countries; therefore, it is necessary to develop indicators of land efficiency measurement systems and ways of calculating economic land efficiency.

4. In order to increase the use of agricultural land, it is necessary to financially motivate and support existing and new farms.

\section{Acknowledgments}

Publications are co-financed from the LLU program "Strengthening scientific capacity at the LLU”, project Z17.

\section{References}

1. Allahyari, M.S., Poshtiban, A., \& Koundinya, V. (2013). Effective Factors on Agricultural Land Use Change in Guilan Province, Iran. Mediterranean Journal of Social Sciences MCSER Publishing, RomeItaly. Nr.11, 744-751. Retrieved March 5, 2018, from: http://www.mcser.org/journal/index.php/mjss/ article/viewFile/1365/1393.

2. Auziņš, A. (2016). Zemes izmantošanas novērtēšana un pārvaldība. (Land use assessment and management) Riga Technical University, Rīga: RTU. 270 lpp. (in Latvian).

3. Baumane, V., Celms, A., \& Ratkevics, A. (2014). Assessment for determination possibilities of land use economic efficiency. In: Proceedings of 13th International scientific conference: Engineering for rural development. May 29 - 30, 2014, pp. 535-540. Latvia, Jelgava.

4. Daba kā kapitāls (Nature as capital) (2015). Eiropas komisijas mājaslapa. (European Commission home page). Retrieved March 5, 2018, from: http://ec.europa.eu/environment/basics/natural-capital/index_ lv.htm. (in Latvian).

5. Guidelines for land-use planning (1993). Food and agriculture organization of the United Nations. Rome. Soil Resources, Management and Conservation ServiceInter-Departmental Working Group on Land Use Planning. Retrieved March 5, 2018, from: http://www.fao.org/docrep/t0715e/t0715e00.htm\#Contents.

6. Pilvere, I. (2014). Gala atskaite par projektu "Zemes ekonomiski efektīva, ilgtspējīga un produktīva izmantošana lauksaimniecības un mežsaimniecības produkcijas ražošanai”. (Final report on the project "Economically efficient, sustainable and productive use of land for the production of agricultural and forestry products") Retrieved March 5, 2018, from: http://www.lvm.lv/images/lvm/Petijumi_un_ publikacijas/Petijumi/Atskaite_zemes_janvaris_gala_2014_1.pdf. (in Latvian). 
7. Галечян, Г.А. (2014). Эффективность использования почвенно земельных ресурсов саратовской области. (Efficiency of land use in the Saratov region). Саратовский государственный социальноэкономический университет Саратов, (Saratov State Social and Economic University) Saratov, Russia Retrieved March 5, 2018, from: https://www.scienceforum.ru/2014/592/1654. (in Russian).

8. Изиев, А.И., \& Шейхов, М.А. (n.d.). Экономическая эффективность использования земельных ресурсов в условиях рыночных отношенийю (Economic efficiency of use of ground resources in the conditions of market relations) Retrieved March 5, 2018, from: http://www.rppe.ru/wp-content/ uploads/2010/02/iziev-ai-sheikov-ma.pdf. (in Russian).

9. Колобова, А.И. (2008). Организация производства на предприятиях АПК. (Organization of production at the enterprises of agroindustrial complex) Hand-book 397 c. Retrieved March 5, 2018, from: http://eclib. net/28/27.html. (in Russian).

10. Мишина, А. (2011). Эффективность использования земельных ресурсов в хозяйствах всех категорий Нижегородской области. (Efficiency of use of land resources in farms of all categories of the Nizhny Novgorod region) Scientific paper. c. 58-77 Retrieved March 5, 2018, from: http://cyberleninka.ru/ article/n/effektivnost-ispolzovaniya-zemelnyh-resursov-v-hozyaystvah-vseh-kategoriy-nizhegorodskoyoblasti. (in Russian). 